\title{
INTEGRATION OF SCIENCE, TECHNOLOGY, AND ISLAMIC VALUES TO ENHANCE EXPECTED LEARNING OUTCOMES IN FRENCH HIGHER EDUCATION
}

\section{Elis Ratna Wulan}

UIN Sunan Gunung Djati Bandung

Jl. A. H. Nasution 105 Bandung, Indonesia, 40614

Email: elis_ratna_wulan@uinsgd.ac.id

\section{Heri Gunawan}

UIN Sunan Gunung Djati Bandung

Jl. A. H. Nasution 105 Bandung, Indonesia, 40614

Email: heri.gunawan@uinsgd.ac.id

\section{Wafi Fauziah}

UIN Sunan Gunung Djati Bandung

Jl. A. H. Nasution 105 Bandung, Indonesia, 40614

Email: fauziahwafi8@gmail.com

\section{Frederic Kratz}

PRISME Laboratory, INSA Centre Val de Loire

Bourges 18000 France

Email: frederic.kratz@insa-cvl.fr

Received: 06, 2021 Accepted: 06, 2021 Published: 06, 2021

\begin{abstract}
Learning strategies like integrating Islamic values into learning can be applied to improve learning outcomes. Integrating Islamic values into learning science and technology provides opportunities for students to integrate science and technology with concepts and experiences in real life as Muslims so that they can feel that their learning is meaningful. This study aims to investigate the effect of learning science and technology that is integrated with Islamic values on the expected learning outcomes (ELO) of students. The learning material covers the basic material of science and technology. The population included lecturers and second-year students of the Institut National des Sciences Appliquées (INSA) Bourges France. Data were analysed using the Revised Ones Assignment Method. The results show that learning science and technology integrated with Islamic values has a significant effect on the expected learning outcomes of students. To achieve this, a minimum cost incurred by universities in France of 38 Euros was spent for six lecturers. They were assigned to ensure that students could explain education and its various terms (ELO1), the basis and scope of Islamic Education (ELO2), the objectives of Islamic Education (ELO3), Islamic Education methods (ELO4), Islamic Education material (ELO5), and Islamic Education evaluation (ELO6).
\end{abstract}

Keywords: Expected Learning Outcome, French Educational System, Integrated Learning, Islamic Values, Revised Ones Assignment (ROA) method

\section{ABSTRAK}

Strategi pembelajaran dengan mengintegrasikan nilai-nilai Islam ke dalam pembelajaran dapat diterapkan untuk meningkatkan hasil belajar. Mengintegrasikan nilai-nilai Islam ke dalam pembelajaran iptek. memberikan kesempatan kepada mahasiswa untuk mengintegrasikan iptek dengan konsep dan pengalaman dalam kebidupan nyata sebagai umat Islam sehingga mereka dapat merasakan bahwa pembelajarannya bermakna. Penelitian ini bertujuan untuk mengetabui pengaruh pembelajaran iptek yang terintegrasi dengan nilai-nilai Islam terbadap expected learning outcomes 
(ELO) mahasiswa. Materi pembelajaran meliputi materi dasar ilmu pengetahuan dan teknologi. Populasi terdiri dari dosen dan mahasiswa tabun kedua Institut National des Sciences Appliquées (INS A) Bourges France. Data dianalisis dengan menggunakan metode revised ones assignment. Hasil penelitian menunjukkan babwa pembelajaran iptek yang terintegrasi dengan nilai-nilai Islam berpengaruh signifikan terbadap hasil belajar yang dibarapkan mahasiswa. Untuk mencapai hal tersebut, biaya minimal yang dikeluarkan oleh universitas di Prancis sebesar 38 Euro dihabiskan untuk. enam orang dosen. Mereka ditugaskan untuk. memastikan bahwa mahasiswa dapat menjelaskan pendidikan dan berbagai istilahnya (ELO1), dasar dan ruang lingkup Pendidikan Islam (ELO2), tujuan Pendidikan Islam (ELO3), metode Pendidikan Islam (ELO4), materi Pendidikan Islam (ELO5), dan evaluasi Pendidikan Islam (ELO6).

Kata Kunci: Expected Learning Outcome, Nilai-nilai Islam, Metode Revisi Ones Assignment (ROA), Pembelajaran Terpadu, Sistem Pendidikan Perancis

\section{INTRODUCTION}

France is geographically divided into 31 educational regions known as academies for administrative purposes. Each académie is led by a recteur, a representative of the Ministry of Education, who is in charge of all education levels within that region. Each academie is further divided into départements, which are headed by an $i a$, who oversees primary and secondary education. A law adopted in 1989 established that while the Ministry of Education is responsible for creating the curriculum and setting educational standards and goals, each primary and secondary school has the autonomy to choose how to best teach the curriculum and achieve state-determined educational goals (Magaziner, 2015). The freedom for the schools should be managed to serve and cater best educational practices for the students.

In France, the state determines education goals that determine the educational practice to implement by schools' institution. On the other hand, Islam as religion has educational objectives to achieve in Islamic education. In Islam, the education is not exclusively pointed toward acquiring scholarly and material fulfillment. It encompasses other common accomplishment for students to achieve. The religion frames reasonable and understandable view that individuals should perceive the all-powerful Allah as the maker of man and the universe (Ma'zumi and Jakaria, 2012). This aim can be a significant premise of the lecturers' endeavours to accomplish the students expected learning outcome. The lecturers are in the position to create the space and opportunity which are dynamic and supportive for learning interaction.

The government of France encourages many institutions in higher education to apply education method that is called an outcome-based education (OBE). OBE can be described as a way in which a curriculum is defined, organized, and directed based on all the things that learners would learn and demonstrate successfully when they complete a particular study program. The focus of OBE is on the results of learning. It consists of knowledge, skills, and attitudes that learners are expected to master. They are clearly identified and expressed as expected learning outcomes (ELO). ELO are formulated and designed in accordance with the needs of stakeholders. It should be designed and started as a design of an academic program. $\mathrm{OBE}$ is concerned with the achievement of the learner, rather than the intention of the teacher. It is often written as educational aims, goals, or objectives of a particular program. ELO should be written in a way where learning is translated into observable and measurable results which can be demonstrated and assessed (Hussey \& Smith, 2002). Those observable behaviours are crucial for educators when it comes to assessment in higher education.

France government has appointed the institution that is responsible to secure education quality that is Accreditation associations. This institution reaffirms that Higher Education Institutions (HEI) are liable for the quality affirmation of their examination programs. This implies that the principal responsibility for setting and characterizing ELO lies in the hand of 
the HEI. To help HEI in this errand, accreditation associations think about the part of ELO in their outer quality confirmation methodology. The institution has managed to improve the utilization of ELO evaluation as a vital piece of students' learning measurement (Heusser, 2006). To measure students' competence and their ELO, the education system of OBE has something to offer for educator to ensure the quality outcome for their education.

In Europe, especially in France, ELO are characterized as statements of what a student is required to know and comprehend. The statements emphasize things to achieve when students finish their time of learning. European Consortium for Accreditation (ECA) has been pushing a more grounded centre around ELO in quality confirmation systems since 2006. The significance of ELO is identified with quality affirmation that has been affirmed in the Bucharest Communiqué. The union of the European Higher Education Area (EHEA) is connected unequivocally to the significant execution of ELO under different viewpoints, including quality assurance (Heusser, 2006). Quality assurance is one of the pivotal aspects to take into consideration by this union.

Islamic values can be integrated into learning material by coordinating materials on Islamic subjects (Quran and Hadith, Aqidah and Akhlak, and Fiqih) with the science and technology materials (Hakim, 2012). To achieve this mission, the lecturers are required to have the ability to utilize the proper techniques to deliver in learning (Hassan, 2010). Proper technique is in a position to help the instructor to deliver and integrate Islamic values into learning material. In addition to teaching technique, teachers' Islamic knowledge plays important role to assist them in integrating Islamic values into learning material. The teachers who do not have adequate Islamic knowledge will not be able to integrate the learning material with the Islamic values (Suhailah \& Hisham, 2011; Hashim \& Abdallah, 2013). A proper Islamic knowledge may boost teachers' performance in integrating Islamic values into learning material. A blend of substance material and the assurance of scholastic abilities and intelligent abilities to some extent enable the teachers to give a positive effect on teaching and learning improvement (Kudari, 2016). Teaching and learning improvement will be boosted by the lecturers' knowledge in their respective field including Islamic religious education.

The procedure of integrating Islamic values in science and technology learning should be possible. The procedure entails applicable refrains of Quran and Hadith into the science and technology to enrich and develop learning material (Hariyani, 2013). It provides the indications of the force and grandness of Allah almighty on different scientific and technological objects (Muspiroh, 2016). In addition, the procedure should uncover the advantages featured and contained in Islamic teachings. Lecturers can engage students in using learning assets that empower them to gain lesson an insight from the Quran. Potential students who comprehend what they learn from Islamic values can start adapting eagerly and take an interest in learning (Purwati, 2018). Islamic value knowledge to some extent provides more chance and opportunities to boost students' character that is in line with Islamic religion.

Research on the impact of integrating Islamic values in learning toward different parts of ELO have not been conducted in countries that apply secularism in their educational program (van den Kerchove, 2018). In other words, studies have reported mainly the practices of Islamic values integration into learning material in countries that have Muslim majority. It appears that there is a need to investigate ELO which is influenced by learning procedure integrated with Islamic values.

Studies reporting the Islamic integration into learning material has been conducted by researchers. One of them is the integration of Islamic values in learning English with respect to their competence in integrating Islamic values into the teaching and learning process of English (Wijayanto, 2020). It seems that there is a dichotomous view of science and 
technology with the religious consequences of ambivalence in the Islamic education system (Hidayat et al., 2020). On the one hand, it considers the issue of Islamic educational institutions, not the main areas to be assessed. On the other hand, modernization of the Islamic education system should be included in the general education curriculum. The curriculum should adapt the religious aspect to empower the education for students.

The integration of Islamic values into science and technology in the learning process is a necessity to improve the quality of Islamic education. The quality of Islamic education is still lagging. Through this integration, the universality of Islamic values will underlie the development of science and technology and also the continuity of the educational process. Integration efforts are expected to empower the existence of Islamic educational institutions more effectively. This integration effort implements transformation of Islamic values into science and technology. The implementation of the educational process can bring benefits to the welfare of mankind as a whole. In addition, this integration eliminates the negative effects of science and technology as the basis for the modernization which is sometimes contrary to the humanitarian, cultural, and religious values (Hidayat et al., 2020).

The French republican principles upon which public education is based include strict separation of religion from schooling. In other words, schools have no authority to deliver religious subjects in the educational institution. At the same time, public funds subsidize a large number of private schools, over 90\% Catholic. Other religions like Islam and Jewish do not have a good financial support from the government. In other words, no recognition or public support is provided for the schools affiliated with Muslim or Jewish (Limage, 2000).

Research on increasing ELO through the integration Islamic values in France Higher Education by considering education cost has not been widely conducted. The objective of this research is in line with the complex and changing context of Muslim identity that has evolved in France. This can be done by determining the optimum education cost incurred by the higher education in order to increase ELO through the integration of Islamic values in science and technology learning.

This study is important since it leads to an exploration, particularly on scientific and technological fundamentals that plans to examine the impact of science and technology learning incorporated with Islamic values. The integration is related to students' ELO in second year lecturers and students in Sciences and Techniques for Engineers of Institut National des Sciences Appliquées (INSA) Bourges France. The second-year lecturers and students were chosen for the research because the students have self-improvement, interest, basic reasoning, enthusiasm, autonomy and cooperation abilities. The aims of the research are to determine the minimum cost education incurred by the French higher education through integrating Islamic values in science and technology learning in order to increase ELO.

\section{METHOD}

The study was conducted in Institut National des Sciences Appliquées (INSA) Bourges France. The population of the study was second year students and lecturers in the 2019/2020 academic year. The research subjects were Muslim students and lecturers of undergraduate program majoring at sciences and techniques for engineers.

The data sources in this study were collected from the results of the integrated science and technology courses with Islamic values test. The research data obtained are then processed using the Revised One Assignment (ROA). This method is a new method for solving assignment problems (Wulan, 2019). The ROA method is based on making some of the items in the assignment matrix then trying to find the complete assignment, as follows Equation 1 (Gowrishankar, 2018): 
Minimize:

$$
Z=\sum_{i=1}^{m} \sum_{j=1}^{n} C_{i j} X_{i j}
$$

Subject to:

$$
\begin{aligned}
& \sum_{j=1}^{n} X_{i j}=1, \text { for } j=1,2, \ldots, n \\
& \sum_{i=1}^{m} X_{i j}=1, \text { for } i=1,2, \ldots, m
\end{aligned}
$$

where $X_{i j}=1$ or 0

$X_{i j}=1$, if there is assignment from source $\mathrm{i}$ to destination $\mathrm{j}$

$X_{i j}=0$, if there is not assignment from source $i$ to destination $j$

The algorithms used in the ROA Method is as follows (Humayra and Mohammad, 2017):

1) Check whether the assignment problem given is balanced or unbalanced.

i. If the given problem is balanced, then go to step 2 .

ii. If the given problem is unbalanced, then balance the matrix by adding a dummy with entry 1.

2) Find the smallest element on each row.

3) Divides all the elements on the row by the smallest element from each row of the reduced matrix.

4) Find the smallest element of each column.

5) Divides all the elements in the column by the smallest element from each column of the reduced matrix.

6) Draw lines in all rows and columns to a minimum to cover the value of one. If the number of lines $(\ell)$ equals the number of rows or columns $(n)$, then the solution is optimal. If not, take the next steps.

7) Select the smallest element that is not covered by the line, then for all elements that are not exposed to the line by the smallest element, for all elements that are affected by the line once the value is fixed and for all elements that are affected by the line twice then it is multiplied by the smallest element.

8) If the number of lines is not the same as the number of rows or columns, then repeat step 7.

9) Find each worker that doing an assignment numbered one in the row and column to find the optimal solution.

10) Calculate the total cost of the solution obtained to determine the optimal total value.

\section{RESULTS AND DISCUSSION}

This research aims to investigate the effect of science and technology learning integrated with Islamic values on students' ELO by allocating lecturers in the achievement of ELO in order to increase ELO with a minimum cost. It focuses on the efficiency of financial aspect for educational institution. The types of data collected is ratio, namely education cost. The data are organized and represented in the assignment table. The cell in the table refers to the education cost incurred when a lecturer is assigned to achieve an expected learning outcome.

In this research, the simulation case in Sciences and Techniques for Engineers of INSA Bourges France is shown. One of the courses offered is Science and technology fundamentals. The subject is one of the courses offered in that department for the students to select. This course has $6 \mathrm{ELO}$ that are integrated with Islamic values. Its ELO can be explained as follows: ELO 1, Islamic education and its various terms; ELO 2, the basis and scope of Islamic Education; ELO 3, the objectives of Islamic Education; ELO 4, Islamic Education methods; ELO 5, Islamic Education material; and ELO 6, Islamic Education evaluation (Jamaluddin, 2021). When it comes to lecturers' religion affiliation with Islam religion, the department has five Muslim lecturers to work on these six ELO, namely lecturer A, B, C, D 
and E. Taking into account the education costs for each ELO, this study determined the assignment of each lecturer to the ELO that will produce the minimum costs for the higher education. This option can be applied by the higher education. It is strengthening the input of higher education components (funding/education costs) (Solihin et al., 2019). The minimum education cost is applied by using Euro for each ELO and it is shown in Table 1.

Table 1. Assignment Problem in Expected Learning Outcome (ELO)

\begin{tabular}{ccccccc}
\hline Lecturer & ELO1 & ELO2 & ELO3 & ELO4 & ELO5 & ELO6 \\
\hline $\mathrm{A}$ & 12 & 10 & 15 & 22 & 18 & 8 \\
\hline $\mathrm{B}$ & 10 & 18 & 25 & 15 & 16 & 12 \\
\hline $\mathrm{C}$ & 11 & 10 & 3 & 8 & 5 & 9 \\
\hline $\mathrm{D}$ & 6 & 14 & 10 & 13 & 13 & 12 \\
\hline $\mathrm{E}$ & 8 & 12 & 11 & 7 & 13 & 10 \\
\hline
\end{tabular}

The problem given is an unbalanced assignment problem, that is, the number of lecturers is not equal to the number of expected learning outcomes. To cope with this problem, it must be converted to the balanced assignment problem by adding a dummy variable (lecturer $\mathrm{F}$ ) with entry 1 . The results of adding dummy variables are shown in Table 2.

Table 2. The Addition Results of Dummy Variables (Lecturer F) in Column

\begin{tabular}{|c|c|c|c|c|c|c|}
\hline$\overbrace{\text { Lecturer }} \mathrm{ELC}$ & ELO1 & ELO2 & ELO3 & ELO4 & ELO5 & ELO6 \\
\hline$\overline{\mathrm{A}}$ & 12 & 10 & 15 & 22 & 18 & 8 \\
\hline B & 10 & 18 & 25 & 15 & 16 & 12 \\
\hline $\mathrm{C}$ & 11 & 10 & 3 & 8 & 5 & 9 \\
\hline $\mathrm{D}$ & 6 & 14 & 10 & 13 & 13 & 12 \\
\hline $\mathrm{E}$ & 8 & 12 & 11 & 7 & 13 & 10 \\
\hline $\bar{F}$ & 1 & 1 & 1 & 1 & 1 & 1 \\
\hline
\end{tabular}

The next stage is to find Muslim lecturer who were assigned to be responsible to deal with one ELO in rows and columns to find the optimal solution. To get a bigger picture on this circumstance, Table 3 describes the data to explain the circumstance.

Table 3. Expected Learning Outcome (ELO) Assignment

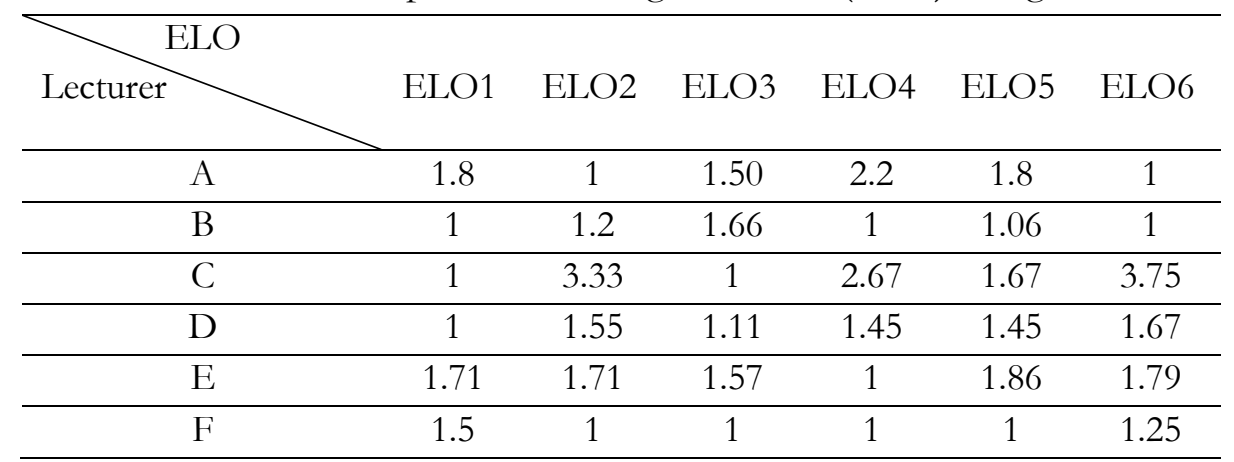

To deal with the need of this study, ROA method is applied. After applying the ROA method, the optimal solution for this simulation can be achieved. After achieving the optimal solution, this study allocated the assignment to increase the expected learning outcomes with the minimum education cost. It also should take other factor into consideration. It calculates 
the total cost of the solution obtained to find out the optimal total value. This is shown in the Table 4.

Table 4. Final Results of The ROA Method

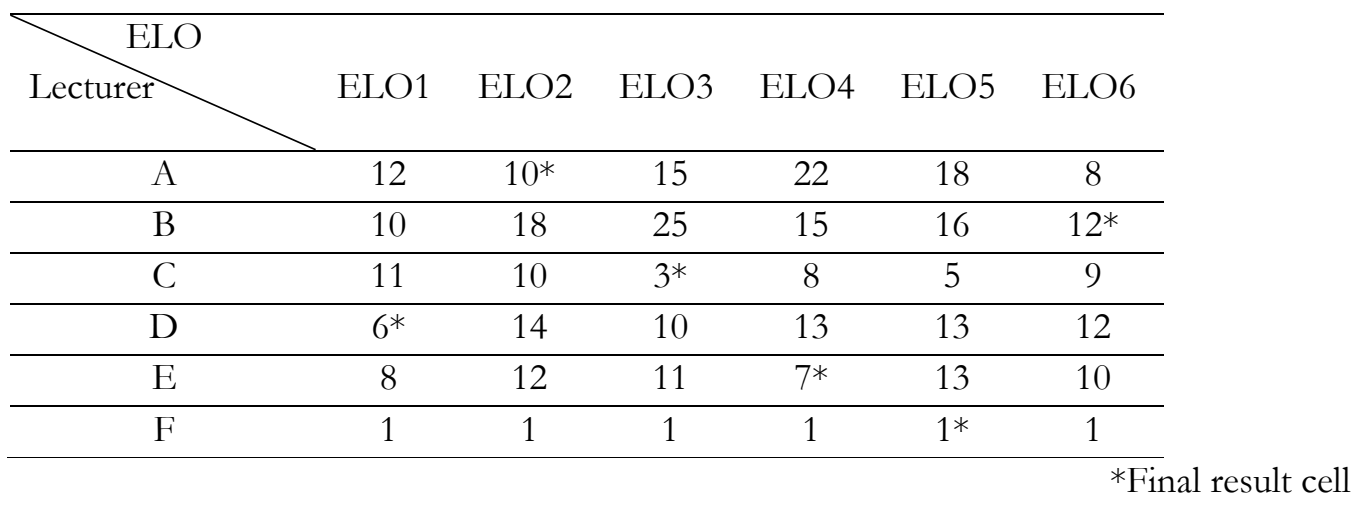

Based on Table 4, the optimal solution to the assignment problem is obtained with a minimum total education cost incurred by the higher education. This optimal solution is applied to achieve six ELO which are integrated with Islamic values. To run this program, 38 Euro was plotted for the budget to finance the activities. An optimal allocation was designed for every lecturer. Lecturer (A) is assigned to ensure the student are able to explain the basic and scope of Islamic Education (ELO2). Lecturer (B) is assigned to ensure that the students are able to explain the Islamic Education evaluation (ELO6). Lecturer (C) is assigned to ensure the students are able to explain the objectives of Islamic Education (ELO3), lecturer (D) is assigned to ensure the students are able to understand education and its various terms (ELO1). Lecturer (E) is assigned to ensure the student are able to explain Islamic Education methods (ELO4). Last, lecturer (F) is assigned to ensure the student are able to explain Islamic Education material (ELO5). It can be seen that each ELO has been assigned to every lecturer in the course to integrate Islamic values into learning material.

Education is a priority in France. To bring this into action, the government allocated 21 percent of the annual national budget for education (Magazer, 2000). This research results can help French Higher Education to optimize the budget to increase the expected learning outcome. The effort to increase expected learning outcome is by integrating Islamic values in science and technology learning by using the ROA method.

This study investigated the implementation of OBE in France educational institution. This educational practice addresses and focuses on outcome of education. In other words, students should be able to achieve educational outcomes or objectives. To achieve this, all resources should be geared toward the outcomes and objectives. The term outcomes in the educational practice have been interchangeably exchanged by other relevant terms like competency, standard, benchmark and attainment. To develop OBE, the skills that students need to achieve should be life skills, basic skills, professional and vocational skill, intellectual skill and interpersonal and personal skill.

There are many benefits of OBE for educational institutions including clarity, flexibility, comparison and involvement. When it comes to clarity, schools have one target to achieve that is the outcomes or educational objectives. The curriculum, the learning activities, teachers will be designed to achieve the outcomes of education. It is clear from the term outcomes that serve as the umbrella for the teaching and learning activities. Flexibility can be achieved when the schools apply OBE. There is no strict method to achieve the outcomes. It provides the space for the teachers to carry out teaching and learning activities to achieve the outcomes or objectives of learning. Teachers are free to select and implement a particular teaching method as long as it enables them to achieve the outcomes or objectives of learning. Comparison 
across educational institutions may be achieved. It enables students who learn with OBE to move from one educational institution to other institutions. It is easier for them to continue learning without being worried that their learning activities will have different situation and circumstance from their previous learning institution.

It should be noted that the acceleration of the use of technology and the innovation is growing very rapidly. This acceleration creates a gap between the world of education and the needs of human resources in the world of work and society. The challenges of education in 21 st century is related to roles and strategies in bridging the gap between the educational process in higher education and the world of work and the need for innovation. One of the approaches used to accommodate 21 st century education is OBE. OBE can be called an approach that emphasizes the sustainability of the learning process in an innovative, interactive, and effective manner. In the process, it affects the entire educational process from curriculum design; learning objectives formulation and achievements; education strategy; the design of learning methods; assessment procedures; and the education environment/ecosystem. In a nutshell, OBE is at the core for other educational aspects in teaching and learning.

OBE is an educational theory that emphasizes the goals of education on every part of the education system. There are many terms used to refer to this theory. Outcome, objectives and the goals are the terms that have one thing in common in education. At the end of the educational experience, student is required to have a single teaching style and assessment to implement OBE. Classes, opportunities, and assessments must help students achieve the specified objectives of education. This results-based method has been adopted in education systems around the world at various levels. Australia and South Africa adopted OBE policies in the early 1990s but they had been eliminated from the educational system. The United States has implemented OBE program since 1994. Hong Kong adopted an OBE since 2005 for its universities. Malaysia implemented OBE in all of their public-school systems in 2008. The European Union has proposed educational changes to focus on outcomes, across the European Union, including France. Furthermore, the OBE was carried out in Canada, Taiwan, Hong Kong, India, Ireland, Japan, Korea, Malaysia, New Zealand, Russia, Singapore, South Africa, Sri Lanka, Turkey, UK, Pakistan, China and the United States. This is to say that OBE has attracted countries all over the world. Its implementation has been widely acknowledged internationally and its success has been reported in many countries.

The education system usually pays attention to three things, input, process, and output. Input focuses on things that can increase educational practices. In education, inputs can be in the form of finance, infrastructure, and others. Those aspects play crucial role in strengthening the input to proceed in learning process. Process has something to do with the aspects of controlling, organizing, and imparting knowledge in learning. Meanwhile, output addresses educational products which were then known as OBE. It can be concluded that input, process and output should be taken into consideration when it comes to education system. Without providing ample opportunity to those three things, education system may face challenges to achieve educational objectives.

OBE is seen as both a theory and philosophy. It requires elaboration in practical action in the form of instructional design, teaching processes, and assessment tools. In this context, learning design should be in line with the OBE philosophy. The delivery of curriculum to achieve learning outcomes for students in this context is very important. The characteristics of OBE include: (1) clear development of learning outcomes that must be met before the end of the learning process; (2) curriculum design, learning strategies, and learning opportunities to ensure the fulfillment of learning outcomes; (3) the assessment process is adjusted to the 
learning achievement and assessment of each student to ensure that learning outcomes are met; and (4). provision of remediation and enrichment.

The idea of the relationship between religion and science (technology) is responded differently among the people, including in France as a Western country. This is inseparable from the sketch of the face of modern science which is closely related to 'materialism'. This world view both ontologically and epistemologically, places matter as the 'centre' of life. This world view is referred to as scientism. It is based on the principles, standards and truths of modern science. Its emphasis is on paradigm and philosophy of life which believes that the boundaries of science can and must be extended to something that was not previously called science and becomes part of that science. The principles and explanations of modern science have denied the relationship (display) between science and religion. According to the viewpoint of scientism, science is objective, religion is subjective; science is real, religion is not real; science is scientific, religion is not scientific. The worldview of scientism is indeed dichotomous. Modern science brought by Western scholars is not only influential in the Western world, but also in the Eastern world, including the Islamic world.

Islamic figures such as Al-Attas and Al-Faruqi offered the idea of Islamization of knowledge. The idea of Al-Attas is based on the scientific reality that developed in the Islamic world and has been co-opted by Western civilization. Western knowledge is built on doubt, confusion, skepticism. It is not built on revelation and religious beliefs so that it becomes secular and does not heed ethical values (Al-Attas, 1984). The Islamic education system has been printed in a Western caricature so that it is seen as a malaise (suffering) experienced by the people (Al-Faruqi, 1986). For Al-Attas and Al-Faruqi, the approach used in stemming Western science and civilization is by recasting the entire wealth of Western knowledge within the framework of Islam which in practice is nothing more than an attempt to rewrite books textbooks in various disciplines with insight into Islamic teachings. Long before that, Ahmad Khan in India (XIX century) and Abduh in Egypt (XX century) had realized the challenges and dangers of Western civilization. However, both of them are considered to have made a mistake in choosing an approach to deal with these challenges. Both of them seek to integrate the Islamic education system with the Western education system by grafting the two systems containing different value foundations so as to create a dichotomy in the Islamic education system and the knowledge system. This model applies and is evenly distributed among Muslims to this day and is believed by the initiators of the Islamization of science as the culprit of all the declines suffered by Muslims (Muhaimin, 2010).

The French state, which so far has adhered to the monadic principle, single entity, restorationist segregation between religious and scientific knowledge), may refer to the view of Islam, not merely the Islamization of knowledge, but also triadic (a bridge between science and religion), interconnected entities and so on. The integration of science between religious science and technological science can strengthen meaningful scholarship. Science is not solely in material cognition, but affective which is spiritual.

The procedures of integrating Islamic qualities in this research empower the students to acquire significant learning outcomes. The integration effort has a position which is significant to focus on Quran and Hadith in learning. The Islamic sources are in a position to enrich and at the same time inspire the learning material (Sabki \& Hardaker, 2013). To integrate the learning material with Islamic values, the curriculum should be designed to facilitate the attainment of learning objectives.

In this circumstance, learning material is enriched by the Islamic values. Given this situation, the students should be able to relate the science and technology knowledge with the knowledge they acquire from the fundamental ideas of Islam. The fundamental of Islam can be traced from the source of the religion that is Quran and Hadith. This integration allow 
Muslim lecturers and learners to develop their knowledge and characters as Muslims. Each science and technology material learned by students can be connected with their everyday life. This connection will actually help students to feel the significance of each learning material. It is expected that their ability to relate and connect what they learn with their daily life. In real life, it is suggested that the learners carry out what they learn from the integration of Islamic values with learning material in their real life as Muslim (Sahlan, 2013; Zubaidah et al., 2017). The learning material is not just practically significant, but also meaningful to be implemented in their memory. It should stay longer in their memory to enable them carry out in their real life.

The procedures of integrating Islamic qualities in this research empower the students to acquire significant learning. The position of significant learning in this context focuses on Quran and Hadith in learning (Sabki \& Hardaker, 2013). In this learning circumstance, the students can relate the science and technology. The knowledge they acquire with the fundamental ideas of Islam and their strict encounters as Muslims. Each science and technology material learned by students and connected with their everyday life will actually want to help students feel the significance of each learning material and carry out them in different parts of life (Sahlan, 2013; Zubaidah et al., 2017). Moreover, it is expressed that the learning material is not only practically significant, yet additionally will be firmly installed in the student' memory, so it is difficult to be neglected.

The utilization of successful learning techniques can assist the teachers to accomplish the ELO in the institution. In this context, learning should be integrated with Islamic values. Other factors play role. It includes a methodology, a system, and a strategy for integrating Islamic values into learning materials. They are important to take into consideration when it comes to integration of Islamic values in learning material (Rustham \& Arifin, 2012; Zubaidah et al., 2017). This integrated learning will urge student to learn better learning material. They are expected to produce better expected learning outcomes. The arrangement of exercise content in science and technology could foster thinking and metacognitive abilities (Hsu, 1994).

The variables that influence the integration of Islamic values into learning material is crucial to consider. Science and technology should pay attention to indicators. The substance of learning source should be interesting and exciting for the students. Accordingly, it may be said that the science and technology learning material is an educational content. Integrating strict learning materials (Islamic qualities) and learning material can improve students' expected learning outcomes (Tatar et al., 2016). Integrating science and technology with Islamic values positively affected students' performance. Their ELO should be achieved if the integration of Islamic values and learning material is applied successfully (Rosida, 2008).

Islamic values are the series of life principles on how human should live it. They are divided into three levels namely (1) necessities (darûriyyat); (2) convenience (hâjizyat); and (3) refinements (kamâliyât). In the legal theory (uisul al-fiqh) of Islam, there is a maxim or the general aim of legislation in Islam. This maxim is expected to realize values through protecting and guaranteeing their necessities (darûriyyât) as well as fulfilling their importance (hâjizyat) and their embellishments (tahsiniyyât) (Akgunduz, 2010). The human basic values consist of life (nafs), reason ('aql), descent (nasab), property (mâl) and religion (dîn). Islam protects these primary human values, and prohibits any violation of them. Islam covers everything in human's life. Therefore, it is challenging for the lecturer to see what kind of Islamic values that they should teach to their students. This is task on the part of the lecturers and stakeholders at higher education to decide and implement in teaching and learning activities. It is impossible to integrate all Islamic values in the instruction. It requires innovative and creative ways to integrate the Islamic values and learning material (Madkur \& Albantani, 2017). 
The present study has a contribution to the body of knowledge. This research result is in line with study conducted by Shah, Muhamad and Ismail (2012). Their studies shows that design, implementation and execution of a curriculum from an Islamic perspective is greatly feasible. It can be achieved when an educational institution is willing to deal with detailed prerequisites, determine existing challenges and declare the superiority of an Islamic model of education grounded in Tawhid.

French educational system may focus on teaching the science material. This study investigates the integration of Islamic values in learning material. The results of this study show that secular models of French education can be Islamised. This study contributes to the development of a science and technology curriculum. Science and technology require Islamic values to enrich and provide meaningful learning material for students (Madkur \& Albantani, 2017).

The results of this study investigate the integration of Islamic values into the science and technology learning in secular curriculum. The education model in France education system can be improved in the field of science and technology. In the same time the education should empower the quality of faith and devotion (Hariyani, 2013). The integration of Islamic values into the related parts of science and technology learning is an attempt to develop a muslim personality among students. To make Islamic teachings as a guide for life, the education should be designed to be integrated with Islamic values.

This integration form a balanced person physically, intellectually, spiritually and emotionally (Ramli, 2014; Kasim \& Yusoff, 2014). The integration is done in order that the Muslim students do not fall into the teachings that are contrary to the akidah and faith in secularism education system (Djudin, 2011). This can be achieved when educational institution is able to integrate Islamic values in learning material.

The secularism that applied in French education system become an obstacle to integrate Islamic values in the science and technology learning. The process of integrating the Islamic values into science and technology learning in order to increase the ELO can be done by inserting the relevant verses of Quran or Hadith into the content of science and technology learning material. Further research is needed to reveal the effect of the learning integrated with Islamic values on the other aspects, such as students' metacognitive skills and attitudes.

\section{CONCLUSION}

Learning science and technology that is integrated with Islamic values significantly affects the ELO. Optimal assignment allocation with a minimum total tuition fee of 38 Euros for six lecturers can improve learning outcomes. Islamic values that are integrated in science and technology learning are sourced from the Quran and Hadith. The way to integrate Islamic values into science and technology learning must be done with different procedures, for example, by incorporating important parts of the Quran or Hadith into the substance of science and technology learning materials. Based on the integration of science and technology learning and Islamic values, students can explain education and its various terms, the basis and scope of Islamic Education, objectives of Islamic Education, methods of Islamic Education, Islamic Education materials, and evaluation of Islamic Education.

\section{BIBLIOGRAPHY}

Abdallah, S. S., Suhailah H. S., \& Hisham, N. A. (2011). The Experience of Islamization of Knowledge at the International Islamic University Malaysia, in New Intellectual Horizons in Education, ed. Yedullah Kazmi. Kuala Lumpur: IIUM Press. Retrieved from http://irep.iium.edu.my/id/eprint/14493 
Akgunduz, A. (2010). The Values and Norms of Islam. The Journal of Rotterdam Islamic and Social Sciences, 1(1), 1-20. https://doi.org/10.2478/jriss-2013-0008

Djudin, T. (2011). Inserting Religious Values into Science Learning: Alternative Efforts to Strengthen the Students' Aqidah. Khatulistiwa, 1 (2), 151-160. https://doi.org/10.24260/ khatulistiwa.v1i2.188

Gowrishankar, C., Dharshinee, R. Priya, T. P. (2018). Solving Unbalanced Assignment Problem for Using Revised Ones Assignment Method. International Journal of Mathematical Archive, 9(12), 58. Retrieved from http://www.ijma.info/ index.php/ijma/article/view/5899

Hakim, L. (2012). Internalisasi Nilai-nilai Agama Islam dalam Pembentukan Sikap dan Perilaku Siswa Sekolah Dasar Islam Terpadu Al-Muttaqin Kota Tasikmalaya. Jurnal Pendidikan Agama Islam-Ta'lim, 10 (1), 67-77. Retrieved from http://jurnal.upi.edu/taklim /view/2263/internalisasi-nilai-nilai-agama-islam-dalam-pembentukan-sikap-danperilaku-siswa-sekolah-dasar-islam-terpadu-al-muttaqin-kota-tasikmalaya.html

Hariyani, M. (2013). Integrasi Nilai-nilai Islam dalam Pembelajaran Matematika di SD/MI Integration of Islamic Values in Mathematics Learning in SD/MI. Jurnal Primary, 05(01), 1-12. http://dx.doi.org/10.33578/jpfkip.v5i1

Hariyani, M. (2013). Strategi Pembelajaran Matematika Madrasah Ibtidaiyah Berintegrasi NilaiNilai Islam. Menara Riau, 12(2), 150-155. Retrieved from http://ejournal.uinsuska.ac.id/index.php/Menara/article/view/418

Hashim, R. \& Abdallah, S. S. (2013). Islamization of Human Knowledge in Theory and Practice: Achievements, Challenges and Prospects in the IIUM Context. IIUM Journal of Educational Studies, 1(1), 1-12. https://doi.org/10.31436/ijes.v1i1-2.18

Hassan, M. K. (2010). A return to the Qur'anic paradigm of development and integrated knowledge: The Ulu al-Albab model. Intellectual Discourse, 18(2), 183-210. https://journals.iium.edu.my/intdiscourse/index.php/id/article/view/158

Heusser, R. (2006). Mutual recognition of accreditation decisions in Europe. Quality in Higher Education, 12(3), 253-256. https://doi.org/10.1080/13538320601051028

Hidayat, M. C., Arifin, S., Asrori, Rusman. (2020). Integration Science Technology with Islamic Values: Empowering Education Model. Proceedings of the 1st Borobudur International Symposium on Humanities, Economics and Social Sciences (BIS-HESS 2019). https://doi.org/10.2991/ assehr.k.200529.202

Hsu, T. E. (1994, Februari). Effects of Learner Cognitive Styles and Metacognitive Tools on Information Acquisition Paths and Learning in Hyperspace Environments. Proceedings of Selected Research and Development Presentations at the 1994 National Convention of the Association for Educational Communications and Technology. Retrieved from https://eric.ed.gov/?id=ED373721

Hussey, T., \& Smith, P. (2002). The Trouble with Learning Outcomes. Active Learning in Higher Education, 3(3), 220-233. https://doi.org/10.1177\%2F1469787402003003003

Jamaluddin, D. (2021). Rencana Pembelajaran Semester (RPS). Islamic Education Courses, English Department.

Kasim, T. S. A. T., \& Yusoff, Y. M. (2014). Active Teaching Methods: Personal Experience of Integrating Spiritual and Moral Values. Religious Education, 109(5): 554-570. https://doi.org/10.1080/00344087.2014.956560

Kudari, J. M. (2016). Survey on factors Influences the Student's Academic Performance. International journal of Emerging Research in Management \& Technology, 5(6): 30-36. Retrieved from https://pingpdf.com/ pdf-survey-on-the- factors-influences- the- studentsacademic- performance.html 
Limage, L. (2000). Education and Muslim Identity: The Case of France. Comparative Education, 36(1), 73-94. Retrieved from http://www.jstor.org/stable/3099852

Madkur, A. \& Albantani, A. M. (2017). Instilling Islamic Values in Foreign Language Teaching: An Indonesian Context. Advances in Social Science, Education and Humanities Research, volume 115, 3rd International Conferences on Education in Muslim Society (ICEMS 2017). https://doi.org/10.2991/icems-17.2018.20

Magaziner, J. (2015). Education in France. Available at https://wenr.wes.org/ 2015/09/education-france

Ma'zumi \& Jakaria. (2012). Contributions of Madrasah to The Development of the Nation Character. International Journal of Scientific \& Technology Research 1(11). Retrieved from http://www.ijstr.org/final-print/dec2012/Contributions-Of-Madrasah-To-The-

Development-Of-The-Nation-Character.pdf

Muspiroh, N. (2016). Integrasi Nilai Islam dalam Pembelajaran IPA (Perspektif Pendidikan Islam). Jurnal Pendidikan Islam, 28(3), 484-498. https://doi.org/10.15575/jpi.v28i3.560

Purwati, N. Zubaidah, S., Corebima., Duran, A., Mahanal, S. (2018). Increasing Islamic Junior High School Students Learning Outcomes through Integration of Science Learning and Islamic Values. International Journal of Instruction, 11(4), 841-854. Retrieved from https:// files.eric.ed.gov/ fulltext/EJ1191552.pdf

Ramli, M. (2014). Integrasi Pendidikan Agama Islam ke dalam Mata Pelajaran Ilmu Pengetahuan Alam di Madrasah Tsanawiyah Negeri Mulawarman Banjarmasin. Ittihad, 12(21), 111-132. https://dx.doi.org/10.18592/ittihad.v12i21.1677

Rosidah. (2008). The Effect of the Integration of Science and Islam using Discussion Method on Biology Learning Results with the Sub Subject of Archaebacteria to Class X Students of Madrasah Mu'allimat Muhammadiyah Yogyakarta in 2007/2008 Academic Year. Unpublished master's thesis. UIN Sunan Kalijaga, Yogyakarta.

Rustham, N. \& Arifin, M. A. A. R. (2012). Teaching Methodologies in a Weekend Madrasah: A Study at Jamiyah Education Centre, Singapore. International Journal of Arts and Commerce (IJAC), 1(2), 148-167. Retrieved from https://www.ijac.org.uk/images / frontImages/Vol_1_No_1_/Vol._1_No._2/11.pdf

Sabki, A. A \& Hardaker, G. (2013). The Madrasah Concept of Islamic Pedagogy. Educational Review, 65 (3), 342-356. https://doi.org/10.1080/00131911.2012.668873

Sahlan, A. (2013). Pembelajaran Pendidikan Agama Islam dengan Pendekatan Kontekstual. Jurnal el-hikmah Fakultas Tarbiyah UIN Malang, 8(2), 217-227. Retrieved from http://ejournal.uin-malang.ac.id/index.php/elhikmah/article/view/2241

Shah, M. I. A., Muhamad, A. J., \& Ismail, S. M. (2012). Design, Formulation and Implementation of an English Language Curriculum from Islamic Perspective. Journal of Islam, 9(2). https://doi.org/10.31436/JIA.V9I2.353

Solihin, M., Jalaludin, J., Novita, M., \& Ismail, M. S. (2019). SWOT Analysis on The Transformation of Islamic Higher Education. Jurnal Pendidikan Islam, 5(2), 159-174. https://doi.org/10.15575/jpi.v5i2.3107

Tatar, E., Tüysüz, C., Tosun, C., \& İlhan, N. (2016). Investigation of Factors Affecting Students' Science Achievement According to Student Science Teachers. International Journal of Instruction, 9(2), 153-166. https://doi.org/10.1007/978-3-319-64683-1_31

Wulan, E. R., Jamaluddin, D., Hermawan, A. H., Ratnasih, T. (2019). The Application of Assignment Problem Optimal Solution Using Ones Assignment Method in The Curriculum Developer Team. 2019 IEEE 5th International Conference on Wireless and Telematics (ICWT), 16. https://doi.org/10.1109/ICWT47785.2019.8978255 
Zubaidah, S., Fuad, N. M., Mahanal, S., \& Suarsini, E. (2017). Improving Creative Thinking Skills of Students through Differentiated Science Inquiry Integrated with Mind Map. Journal of Turkish Science Education, 14(4), 77-91. Retrieved from http://www.tused.org/index.php/tused/article/view/175

Wijayanto, M. E. (2020). The Integration of Islamic Values in Implementation of Learning English: Islamic Education Students Perspective. ETERNAL (English, Teaching, Learning, and Research Journal), 6(1), 18-30. https://doi.org/10.24252/ Eternal.V61.2020.A2 